\title{
Effect of Temperature, Thermal Requirements and Prey Type on the Biology of Typhlodrompis enab El-Badry (Phytosiidae)
}

\author{
A. M. Metwally*; M. M. Al-Azzazy*; N. M. Abd El-Wahed ${ }^{* *}$ and A. M. El-halawany** \\ *Dept. of Agric. Zoology and Nematology, Fac.of Agric., Al-Azhar Univ., Cairo, Egypt \\ **Fruit Acarology Dept., Plant Protec. Res. Inst., Agric. Res. Cent., Giza, Egypt.
}

\begin{abstract}
This work was conducted to determine the effect of temperature and prey type on the biology of Typhlodrompis enab El-Badry (Acari: Phytosiidae). This phytoseiid was reared on three tetranychids, (i. e. Eutetranychus orientalis (Klein), Tetranychus urticae Koch and Panonychus ulmi (Koch)) at $20,25,30^{\circ} \mathrm{C}$ and $65 \pm 5 \%$ R.H. All life cycle parameters decreased as temperature increased. Obtained relative values for males were generally less than those of females. E. orientalis was the preferred one followed by T.urticae and the least was P. ulmi.
\end{abstract}

Key words: Biology, Typhlodrompis enab, Temperature, Tetranychidae.

\section{INTRODUCTION}

Plant inhabiting predacious mites play a considerable role in biological control of phytophagous mites. Typhlodrompis enab El-Badry is a common phytosiid mite on fruit trees in Egypt (El-Badry 1967, and Farid et al. 2011). Spider mites problem increased when natural enemies are destroyed by applications of broad spectrum insecticides, applied against other pests (Mainul Haque et al., 2010). The phytoseiid mite of the genus Typhlodrompis has gained a great economic importance as a biocontrol agent and can successfully be used in the integrated pest management program (IPM) to control phytophagous mites. In a survey of the mites in apple and apricot orchards in Egypt in 1984-86, Agistemus exsertus and Amblyseius $e n a b$ were recorded as the most important predators attacking the populations of Tetranychus arabicus, Panonychus ulmi and Aculus schlechtendali in apple orchards and $A$. enab was also very active attacking Cenopalpus pulcher in apricot orchards. The predatory mite $T$. ena $b$ was found on leaves of citrus, apple, grape orchard in Giza, Dakahlia, Qualubia and Fayoum Governorates, Egypt, (El-Halawany et al. 1990).

The current study was carried out to study biological aspects of this phytosiid by feeding on three phytophagous mites (i.e. the citrus brown mite, Eutetranychus orientalis (Klein); the two spotted spider mite, Tetranychus urticae Koch, and European red mite, Panonychus ulmi (Koch)) at 20, 25 and $30^{\circ} \mathrm{C}$.

\section{MATERIALS AND METHODS}

Culture of T. enab was established at a laboratory in Plant Protection Research Institute. Stock culture of T. enab was maintained on T. urticae as prey on lima bean leaves in a controlled rearing room ( $25 \pm$ $2^{\circ} \mathrm{C}$ and $65 \pm 5 \%$ R.H). Twenty discs of fresh citrus, grape and apple leaves $(3 \mathrm{~cm}$. diameter) were placed on wet cotton in Petri dishes $(10 \mathrm{~cm}$. in diameter) for $E$. orientalis, T. urticae and P. ulmi, respectively. Every Petri dish contained four discs. Each disc was surrounded with wet cotton as barrier to prevent mite escape. Newly deposited eggs in the stock culture were transferred singly to these discs. Immature stages and adults of prey types were added later on as food source. The rearing discs were checked twice daily and the numbers of consumed prey were recorded and replaced by new ones all over the predator life span. The rearing experiment was carried out at 20,25 and $30^{\circ} \mathrm{C}$ and $65 \pm 5 \%$ R.H. Food source as immatures and adults of $\bar{E}$. orientalis, $T$. urticae and P. ulmi were field collected from leaves of citrus, grape and apple located at Qualubia, Dakahlia and Giza Governorates, respectively. Statistical analysis of obtained data was conducted using Procs ANOVA and Reg in SAS (SAS Institute 1988).

\section{RESULTS AND DISCUSSION}

The present study was conducted to determine the effect of different temperatures and prey type on the duration of various life stages, of T. enab.

\section{Developmental durations:}

Obtained results are presented in Table (1). In general temperature increase decreased developmental duration regardless tested prey; while different prey types resulted in different preferences.

Incubation period: Incubation period of $T$. enab female averaged $3.7,3.7$ and 3.9 days at $20^{\circ} \mathrm{C} ; 2.3$, 2.3 and 2.5 days at $25^{\circ} \mathrm{C} ; 1.9,2.0$ and 2.1 days at 30 ${ }^{\circ} \mathrm{C}$ when reared on E. orientalis, T. urticae and $P$. ulmi, respectively. On the other hand for male it durtated $3.4,3.4$ and 3.6 days at $20^{\circ} \mathrm{C} ; 2.1,2.1$ and 
Table (1): Mean developmental times (days) of T. enab different stages when fed on tetranychids at constant temperatures

\begin{tabular}{|c|c|c|c|c|c|c|c|c|c|c|}
\hline Prey & Temp. & Sex & Egg & Larva & Protonymph & Deutonymph & Life cycle & Longevity & Generation & Life span \\
\hline \multirow{6}{*}{ E. orientalis } & \multirow{2}{*}{20} & 온 & 3.7 & 2.6 & 3.6 & 3.8 & 13.7 & 29.5 & 16.5 & 43.2 \\
\hline & & $0^{\pi}$ & 3.4 & 2.4 & 3.4 & 3.6 & 12.7 & 19.9 & - & 32.6 \\
\hline & \multirow{2}{*}{25} & q & 2.3 & 2.1 & 2.8 & 2.9 & 10.1 & 21.3 & 11.6 & 31.4 \\
\hline & & $0^{\pi}$ & 2.1 & 1.7 & 2.4 & 3.0 & 9.1 & 14.7 & - & 28.8 \\
\hline & \multirow{2}{*}{30} & 오 & 1.9 & 1.6 & 2.1 & 2.5 & 8.3 & 16.8 & 9.4 & 25.1 \\
\hline & & $\bar{\delta}$ & 1.8 & 1.4 & 2.1 & 2.3 & 7.6 & 12.2 & - & 19.9 \\
\hline \multirow{6}{*}{ T. urticae } & \multirow{2}{*}{20} & q & 3.7 & 3.1 & 3.6 & 3.9 & 13.7 & 27.4 & 16.6 & 41.3 \\
\hline & & $\hat{0}$ & 3.4 & 3.1 & 3.3 & 3.6 & 13.4 & 21.6 & - & 35.0 \\
\hline & \multirow{2}{*}{25} & 오 & 2.3 & 2.3 & 2.6 & 3.1 & 10.3 & 21.9 & 12.0 & 32.2 \\
\hline & & $0^{\pi}$ & 2.1 & 2.0 & 2.5 & 2.9 & 9.5 & 15.8 & - & 25.3 \\
\hline & \multirow{2}{*}{30} & 오 & 2.0 & 1.8 & 2.3 & 2.8 & 8.9 & 20.1 & 10.5 & 28.9 \\
\hline & & $0^{\pi}$ & 2.0 & 1.4 & 2.2 & 2.7 & 8.3 & 14.8 & - & 23.1 \\
\hline \multirow{6}{*}{ P. ulmi } & \multirow{2}{*}{20} & 오 & 3.9 & 3.2 & 3.5 & 4.3 & 14.6 & 27.6 & 17.0 & 42.1 \\
\hline & & $0^{\pi}$ & 3.6 & 3.3 & 3.6 & 3.7 & 14.0 & 25.7 & - & 39.7 \\
\hline & \multirow{2}{*}{25} & 오 & 2.5 & 2.7 & 3.0 & 3.4 & 11.1 & 27.1 & 14.2 & 38.6 \\
\hline & & $0^{\pi}$ & 2.5 & 2.6 & 2.8 & 3.3 & 27.1 & 22.0 & - & 33.1 \\
\hline & \multirow{2}{*}{30} & 오 & 2.1 & 2.2 & 2.5 & 3.2 & 10.1 & 25.4 & 11.9 & 35.2 \\
\hline & & $\pi$ & 2.2 & 2.3 & 2.5 & 3.1 & 25.4 & 19.7 & - & 29.7 \\
\hline
\end{tabular}

Table (2) Effect of prey type on the female different durations and aspects regardless tested temperature

\begin{tabular}{lcccccc}
\hline Prey type & Life cycle & Generation & Ovi position & Longevity & Life span & Daily rate \\
\hline T. urticae & $10.83 \mathrm{~b}$ & $12.84 \mathrm{~b}$ & $18.65 \mathrm{~b}$ & $22.91 \mathrm{~b}$ & $33.77 \mathrm{~b}$ & $0.85 \mathrm{~b}$ \\
\hline E. orientalis & $10.33 \mathrm{c}$ & $12.04 \mathrm{c}$ & $17.46 \mathrm{c}$ & $21.68 \mathrm{c}$ & $32.04 \mathrm{c}$ & $1.05 \mathrm{a}$ \\
\hline P. ulmi & $12.01 \mathrm{a}$ & $14.37 \mathrm{a}$ & $22.02 \mathrm{a}$ & $26.66 \mathrm{a}$ & $38.65 \mathrm{a}$ & $0.69 \mathrm{c}$ \\
\hline Lsd & 0.38 & 0.46 & 1.03 & 1.16 & 1.24 & 0.06 \\
\hline
\end{tabular}

Means in the same column followed by the same letter are not significantly different $(\mathrm{P}<0.05)$.

Table (3): Liner regression analysis values for the effect of temperature on $T$. enab developmental rate

\begin{tabular}{|c|c|c|c|c|c|c|}
\hline Stage & Prey type & $\mathbf{a}$ & b & to & $\mathbf{K}$ & $\mathbf{R}^{2}$ \\
\hline \multirow{3}{*}{ Larva } & E. orientalis & -0.074 & 0.022 & 3.36 & 45.45 & 0.946 \\
\hline & T. urticae & -0.139 & 0.023 & 6.06 & 43.67 & 0.991 \\
\hline & P. ulmi & 0.092 & 0.014 & 6.57 & 71.42 & 0.985 \\
\hline \multirow{3}{*}{ Protonymph } & E. orientalis & -0.117 & 0.019 & 6.03 & 51.54 & 0.981 \\
\hline & T. urticae & -0.061 & 0.017 & 3.59 & 58.82 & 0.999 \\
\hline & P. ulmi & 0.074 & 0.010 & 7.40 & 100.00 & 0.998 \\
\hline \multirow{3}{*}{ Deutonymph } & E. orientalis & -0.069 & 0.013 & 5.30 & 76.92 & 0.998 \\
\hline & T. urticae & -0.035 & 0.011 & 3.16 & 90.09 & 0.983 \\
\hline & P. ulmi & 0.078 & 0.008 & 9.67 & 123.45 & 0.922 \\
\hline \multirow{3}{*}{ Generation } & E. orientalis & -0.029 & 0.004 & 7.25 & 250.00 & 0.997 \\
\hline & T. urticae & 0.010 & 0.004 & 2.91 & 285.70 & 0.983 \\
\hline & P. ulmi & 0.008 & 0.003 & 3.20 & 400.00 & 0.998 \\
\hline
\end{tabular}

2.5 days at $25^{\circ} \mathrm{C} ; 1.8,2.0$ and 2.2 days at $30^{\circ} \mathrm{C}$ when fed on these diets, respectively. These periods decreased as temperature increased.

Larval stage: At, $20^{\circ} \mathrm{C}$, T. enab females larval period was 2.6; 3.1 and 3.2 days when fed on E. orientalis, T. urticae and $P$. ulmi, respectively. It was $2.4,3.1$ and 3.3 days when males larva were fed on these diets at $20{ }^{\circ} \mathrm{C}$, respectively. However, when the temperature increased to $25^{\circ} \mathrm{C}$, the larval period was 2.1,2.3 and 2.7 days for females and 1.7, 2.0 and 2.6 days for males, respectively. At $30^{\circ} \mathrm{C}$ female and male larval periods were $1.6,1.4 ; 1.8,1.4$ and 2.2, 2.3 days, respectively.

Protonymphal stage: The mean protonymphal period of $T$. enab female and male was 3.6, 3.4, 3.6, 3.3 and $3.5,3.6$ days when fed on E. orientalis, $T$. urticae and $P$. ulmi at $20^{\circ} \mathrm{C}$, respectively. At $25{ }^{\circ} \mathrm{C}$ this stage period lasted 2.8, 2.6 and 3.0 days for female and 2.4, 2.5 and 2.8 days for males, respectively. At $30^{\circ} \mathrm{C}$ this stage lasted 2.1, 2.2 and 
Table (4): Food consumption of Typhlodrompis enab El-Badry different stages during life span feeding on tetranychids

\begin{tabular}{|c|c|c|c|c|c|c|}
\hline Prey & Temp. & Sex & Total immatures & Oviposition & Longevity & Life span \\
\hline \multirow{6}{*}{ E. orientalis } & \multirow{2}{*}{20} & q & $8.10 \pm 0.9$ & $42.70 \pm 5.1$ & $45.00 \pm 5.3$ & $50.10 \pm 5.7$ \\
\hline & & $\hat{\delta}$ & $5.80 \pm 0.5$ & - & $18.20 \pm 1.9$ & $22.00 \pm 2.2$ \\
\hline & \multirow{2}{*}{25} & $q$ & $7.30 \pm 1.3$ & $58.20 \pm 8.2$ & $60.80 \pm 7.8$ & $68.10 \pm 8.3$ \\
\hline & & $\hat{\delta}$ & $6.00 \pm 0.9$ & - & $33.83 \pm 3.5$ & $39.83 \pm 3.4$ \\
\hline & \multirow{2}{*}{30} & 9 & $6.60 \pm 1.3$ & $51.90 \pm 6.7$ & $54.30 \pm 6.7$ & $60.90 \pm 7.0$ \\
\hline & & $\hat{0}$ & $4.80 \pm 0.8$ & - & $23.40 \pm 3.9$ & $28.20 \pm 4.5$ \\
\hline \multirow{6}{*}{ T. urticae } & \multirow{2}{*}{20} & 9 & $5.40 \pm 0.8$ & $23.10 \pm 3.9$ & $25.60 \pm 3.8$ & $31.10 \pm 3.5$ \\
\hline & & 0 & $4.16 \pm 0.4$ & - & $10.83 \pm 2.1$ & $15.00 \pm 2.5$ \\
\hline & \multirow{2}{*}{25} & 웅 & $7.70 \pm 1.4$ & $49.20 \pm 5.5$ & $52.40 \pm 5.2$ & $60.10 \pm 5.3$ \\
\hline & & $\hat{0}$ & $6.60 \pm 0.6$ & - & $26.80 \pm 1.9$ & $33.40 \pm 1.5$ \\
\hline & \multirow[b]{2}{*}{30} & 오 & $7.10 \pm 1.0$ & $37.10 \pm 5.0$ & $40.80 \pm 4.8$ & $48.00 \pm 5.1$ \\
\hline & & $\frac{1}{0}$ & $5.20 \pm 1.0$ & - & $17.70 \pm 2.2$ & $22.80 \pm 2.3$ \\
\hline \multirow{6}{*}{ P. ulmi } & \multirow[b]{2}{*}{20} & 오 & $4.30 \pm 0.7$ & $8.10 \pm 1.7$ & $10.8 \pm 1.7$ & $15.10 \pm 1.5$ \\
\hline & & $\delta$ & $3.60 \pm 0.6$ & - & $5.8 \pm 0.9$ & $9.40 \pm 1.1$ \\
\hline & \multirow{2}{*}{25} & 오 & $7.90 \pm 1.2$ & $19.40 \pm 3.3$ & $22.8 \pm 3.5$ & $30.75 \pm 3.7$ \\
\hline & & $\hat{0}$ & $5.33 \pm 0.8$ & - & $17.00 \pm 2.0$ & $22.33 \pm 2.3$ \\
\hline & \multirow{2}{*}{30} & 웅 & $7.70 \pm 1.4$ & $26.00 \pm 4.7$ & $29 \pm 4.6$ & $36.70 \pm 5.0$ \\
\hline & & 0 & $5.20 \pm 0.8$ & - & $13.6 \pm 2.1$ & $18.8 \pm 2.2$ \\
\hline
\end{tabular}

2.5 days for females and $2.1,2.2$ and 2.5 days for males when fed on the same prey, respectively.

Deutonymphal Stage: The mean deutonymphal period of T. enab was 3.8, 3.9 and 4.3 days for female when reared on E. orientalis, T. urticae and P. ulmi at $20^{\circ} \mathrm{C}$, respectively. This period was $3.6,3.6$ and 3.7 days for males. This stage lasted $2.9,3.0,3.1 ; 2.9$, and $3.4,3.3$ days for females and males at $25{ }^{\circ} \mathrm{C}$ respectively. On the other hand, the deutonymphal period of T. enab was observed at $30^{\circ} \mathrm{C}$ lasted $2.5,2.8$ and 3.2 days, respectively, Table (1).

Life Cycle: The mean life cycle duration differed according to the type of tested prey and temperature, being $13.7,12.7 ; 13.7,13.4$ and $14.6,14.0$ days when the T. enab females and males fed on E. orientalis, T. urticae and P. ulmi at $20^{\circ} \mathrm{C}$, respectively. However these periods decreased at $30^{\circ} \mathrm{C}$ averaging 8.3, 7.6; $8.9,8.3$ and $9.9,10.1$ days, respectively.

Adult longevity: Mean female longevity was 29.5, 27.4 and 27.6 days at $20^{\circ} \mathrm{C} ; 21.3,21.9$ and 27.1 days at 25 and $16.8,20.1$ and 25.4 days at $30^{\circ} \mathrm{C}$ when fed on E. orientalis, T. urticae and P. ulmi, respectively.

These results are in agreement with Isik 2007 and Abou-Awad et al. 2009. The present study clearly indicated that biological aspects of $T$. enab at different temperatures and prey types on the developmental time of different stages of $T$. enab. Preoviposition and postoviposition period of T. enab were shortened as temperature increased. The oviposition period was longer at 20 than at 25 and 30 ${ }^{\circ} \mathrm{C}$. Total fecundity was significantty higher on $E$. orientalis than T. urticae and P. ulmi. Generation of
T. enab when fed on E. orientalis was the shortest. Male predator life span followed similar trend except having shorter period.

Studied biology of the predatory mite Typhlodromips enab EI-Badry (Acari: Phytoseiidae) were studied at different temperatures under laboratory conditions. Predatory mite females completed their total immature development times in $8.68,6.15$ and 4.73 days at 20,25 and $30^{\circ} \mathrm{C}$, respectively ( $70 \pm 10 \%$ R.H. and 14L: $10 \mathrm{D}$ photo period). Mated females laid an average $0.88,0.57$ and 0.64 eggs per female per day and $4.40,4.63$ and 6.40 , eggs over their the entire lives in the above given temperatures, respectively. Total average life span of T. enab was $21.80,16.49$ and 15.20 days at 20,25 and $30^{\circ} \mathrm{C}$. Cemal et al. (2007). These results are agree with El-Lathy and Fouly (1992), Ali and Zaher (2007), Al-Shammery (2010), El-Moghazy (2010), Foully et al.(2011) and Abbassy et al.(2012).

Effect of prey on the female different durations and aspects regardless tested temperature is presented in Table (2). There was a highly significant difference between them. E. orientalis was the preferred one followed by T.urticae and the least was P. ulmi.

Thermal requirements: Results of applying the linear model to the relation between temperature and rate of development is presented in Table (3). Obtained $\mathrm{R}^{2}$ values of $E$. orientalis $T$. urticae and $P$. ulmi renged between 0.922 and 0.999 for larva, protonymph , deutonymph and generation, respectively. Using the equation resulted in determination of lower thresholds $\left(\mathrm{t}_{\mathrm{o}}\right)$ as $3.36,6.06$, 
$6.57 ; 6.03,3.59,7.40 ; 5.30,3.16,9.67$ and $7.25,2.91$, $3.20^{\circ} \mathrm{C}$. The thermal constant $(\mathrm{K})$ was estimated as $45.45,43.67,71.42 ; 51.54,58.82,100.00 ; 76.92$, $90.09,123.45$ and $250.00,285.70,400.00$ DDs on three phytophagous mites.

\section{Feeding consumption of $T$. enab on tetranychaids different stages:}

Average daily consumption of $T$. enab different stages when fed on E. orientalis, T. urticae and $P$. ulmi is presented in Table (4). The relevant values at $20{ }^{\circ} \mathrm{C}$ were $8.10,5.80 ; 5.40,4.16$ and $4.30,4.60$ individuals for $T$. enab immatures, females and males, respectively. At $25^{\circ} \mathrm{C}$ the relevant values were $7.30,6.00 ; 7.70,6.60$ and $7.90,5.33$ individuals when the female and male fed on these prey types, respectively. At $30^{\circ} \mathrm{C}$, the immature stages of $T$. enab consumed $6.60,4.80,7.10,5.20$ and $7.70,5.20$ individuals, respectively. The average number of consumption of movable stages of these diets increased with the development of the predator stages. During oviposition period, the predator attacked $42.7,31.1$ and individuals at $20^{\circ} \mathrm{C}$, while these results were 58.2, 49.2 and 19.2 individuals at $25^{\circ} \mathrm{C}$. At $30^{\circ} \mathrm{C}$, the average number of consumed prey was $51.9,37.1$ and 26.4 individuals when $T$. enab females fed on these prey types. The average number of consumed prey by adult females during oviposition was more than pre and postoviposition. The predatory mite could consume $45.00,25.60$ and 10.80 individual for female longevity at $20^{\circ} \mathrm{C}, 60.80$, 52.40 and 22.40 individuals, at $25^{\circ} \mathrm{C}, 54.30,40.80$ and 29.00 individual, at $30^{\circ} \mathrm{C}$ on these prey type, respectively. Tested the citrus brown mite $E$. orientalis was more favorable as prey than tested $T$. urticae, and P. ulmi. Thus the present results revealed that, $E$. orientalis was the preferable food and $25^{\circ} \mathrm{C}$ were the most suitable, for mass rearing $T$. enab.

\section{REFERENCES}

Abbassy, M. R.; Hendy, H. H.; Mowafi, M. H. and Nawar, M. A. 2012. Biology of Euseius scutalis (Acari: Phytoseiidae) on Tetranychus urticae and Panonychus ulmi (Acari: Tetranychidae) at different temperature. Acarines, 6: 15-19.

Abou-Awad, B. A.; Metwally, A. M. and Al-Azzazy, M. M. 2009. Typhlodrompis swirskii (Acari: Phytoseiidae) a predator of eriophyid and tetranychid mango mites in Egypt. Acarines, 3: 59-64.

Ali, F. S. and Zaher, M. A. 2007. Effect of food and temperature on the biology of Typhlodrompis swirskii (Athis-Henriot) (Acari: phytoseiidae).
Acarines, 1: 17-21.

Al-Shammery, K. A. 2010. Different biological aspects of the predacious mite Euseius scutalis (Acari: Gamasida: Phytoseiidae) and the effects due to feeding on three tetranychid mite species in Hail, Saudi Arabia. Asian J. Biol. Sci., 3 (2): 77-84.

Cemal, K.; Cengiz, K. and Kamil, K. 2007. Determination of biology of predatory mite Tephlodrompis (Amblyseius) enab El-Badry (Acari: Phytoseiidae) at different temperatures. Turk. Entomol. Derg., 31(2): 129-138.

El-Badry, E. A. 1967. Five new phytoseiid mites from U.A.R., with collection notes on three other species (Acarina: Phytoseiidae). Indian, J. Entomol., 29 (2): 177-184.

El-Badry, E. A.; Afifi, A. M.; Issa, G. I. and ElBanhawy, E. M. 1968. Effectiveness of the predacious mite Amblyseius gossipi as a predator of three tetranychid mites (Acarina: Phytoseiidae). J. Appl. Entomol., 62: 189-194.

El-Halawany, M. E.; Abo El-Ela, R. G. and Ismail, H. M. 1990. Population dynamics of mites and their natural enemies on apple and apricot trees. Agric. Res. Rev., 68: 59-66.

El-Laithy, A.Y. and Fouly, A. H. 1992. Life table parameters of the two phytoseiid predators Amblyseius scutalis (Athis-Henriot) and $A$. swirskii (A. - H.) (Acari: Phytoseiidae) in Egypt. J. of Appl. Entomol., 113: 8-12.

Elmoghazy, M. M. E. 2010. Typhlodrompis swirskii (Athis-Henroit) as a biological control agent for Panonychus citri (Mc) (Gregor) (Phytoseiidae, Tetranychidae). Acarines, 4:11-14.

Farid, F.; Sultan, C. and Ibrahim, C. 2011. A checklist and a key for the phytoseiid species of Turkey with two new species records (Acari: Mesostigmata). Internat. J. Acarology, 37 (1): 221-243.

Fouly, A. H.; Al-Deghairi, M. A. and Abd El-Baky, N. F. 2011. Biological aspects and life table of Typhlodrompis swirskii (Acari: Phytoseiidae) fed Bemesia tabaci (Hemiptera: Aleyroidae) J. Entomol., 8(1): 52-62.

Isik, B. 2007. Some biological characteristics of predatory mite Typhlodrompis enab El-Badry (Acarina: Phytoseiidae) on different food under laboratory conditions. M. Sc. Cukurova University, $59 \mathrm{pp}$.

Haque, M. M.; Asgar, A. and Parvin, M. 2010. Voracity of three predators on two-spotted spider mite, Tetranychus urticae Koch (Acari: Tetranychidae) and their developmental stages. Research Journal of Agriculture and Biological Sciences, 6(1): 77-83.

SAS Institute (1988): SAS/St At user's guide 6.03, ed. SAS Institute, Cary, NC. 